\title{
Kernos
}

Revue internationale et pluridisciplinaire de religion grecque antique

12 | 1999

Varia

\section{J. RABINOWITZ, The Rotting Goddess. The Origin of the Witch in Classical Antiquity's Demonization of Fertility Religion}

Fritz Graf

\section{(2) OpenEdition \\ Journals}

Electronic version

URL: http://journals.openedition.org/kernos/746

DOI: $10.4000 /$ kernos.746

ISSN: 2034-7871

\section{Publisher}

Centre international d'étude de la religion grecque antique

\section{Printed version}

Date of publication: 1 January 1999

Number of pages: $321-322$

ISSN: 0776-3824

\section{Electronic reference}

Fritz Graf, "J. RABINowITz, The Rotting Goddess. The Origin of the Witch in Classical Antiquity's

Demonization of Fertility Religion", Kernos [Online], 12 | 1999, Online since 13 April 2011, connection on

11 March 2021. URL: http://journals.openedition.org/kernos/746 ; DOI: https://doi.org/10.4000/

kernos.746 
Jacob Rabinowitz, The Rotting Goddess. The Origin of the Witch in Classical Antiquity's Demonization of Fertility Religion, New York, Autonomedia, 1998. 1 vol. $15 \times 22,5 \mathrm{~cm}, 153$ p. ISBN : 1-57027-035-x.

This slender book makes a lofty claim: "Here you will find for the first time a complete and comprehensive study of Hekate and the witches for the 1200 year period from Homer to the Greek Magical Papyri" (13). And in its course, it pre sents several new theories. Most interesting is the claim that the actual cult of Hekate originally had not much to do with witchcraft; this latter association was a literary construct of the 5th century B.C. which much later on generated the reality of witchcraft (59); the analysis of "the archetype of the witch" as closely related to the "archetype of the fertility goddess", especially in the ambivalence which embraces both birth and death (80f.); and the view of an evolution of this ambivalence - viewed positively in an archaic cultural background, it resulted in the demonization of the witch from the classical epoch onwards, resulting from "changing Graeco-Roman attitudes to material existence" (121).

None of the claims can really be substantiated, and the book contains some very basic flaws. One such flaw is the author's failure to clarify what he means by witchcraft in Greek and Roman culture: he uses the term as if it were a universal, equally appropriate to the Homeric Circe and the Horatian Canidia, to phenomena in Africa and early modern Europe: witchcraft seems to be any uncanny ritual activity by women. As a corollary, there is no clear differentiation between literary portraits and the description of actual rites: why should Horace. or Lucan be reliable witnesses to witchcraft? The differentiation is arbitrary: while Circe's rites are literature, the rites of Theocritus' Simaitha or Horatius' Canidia are as much actual witchcraft as the rites of the Papyri Graecae Magicae (which, incidentally, misrepresents the PGM: they contain rites of sorcery, but not necessarily witchcraft). A much more precise differentiation is needed, one through which it becomes clear that all female practitioners of sorcery - both of rites which can be assumed as practiced because detailed in the PGM (like necromancy or ritual binding) and of rites which have no such corroboration (like divinatory child sacrifice) - are purely literary creations and, furthermore, do not antedate Hellenistic literature; at least such testimonies for actual sorcery (inscriptions and papyri) attest women very rarely as practitioners, and the generic prescriptions of the papyri assume that all practitioners are male. Thus, the most innovative thesis - that the literary description antedates and causes the actual rite - cannot be confirmed from the material. Looking at the problem from the point of view of language, it should be noted that neither Greek nor Latin had a.specific term for witchcraft, while only Latin had such a term for the female practitioner of sorcery, namely saga; the Greek $\varphi \alpha \rho \mu \alpha \kappa \varepsilon v i \tau p l \alpha$ covers more than that. But with one exception - an inscription which, typically enough, accuses a saga - all texts again are literary ${ }^{1}$; this one exception might suggest that the literary description antedates and influenced not the practice of witchcraft, but the accusations. This, at least, is what happened much later, in the witchcraft of early modern Europe.

Nor can another new claim be substantiated. That benign Hekate of archaic Greece changed into infernal Hekate in the fifth century through the identification with the Thessalian goddess Enodia may have Wilamowitz' authority - but it is too mechanical to be true: even provided that such a character of the Thessalian goddess is correct (in my opinion, the earlier testimonies are too scarce to

1 CIL, VI, 19747 (Verona, Museo Maffeiano, from Rome; aet imp.). 
allow such an assertion): what would have caused the Thessalian goddess to become suddenly so important in all of Greece?

Another flaw - at least in the eyes of this reviewer - is the use of problematical categories: vague concepts like axis mundi or fertility goddess are not really helpful for the understanding of Graeco-Roman religion, and the resuscitation of the distinction between chthonic-olympian in the face of modern deconstruction of it is not convincing either ${ }^{1}$. And even if one deems these categories useful, their relevance should be demonstrated with less flimsy reasoning: if the column in the centre of a Hekataion was the axis mundi, why is it absent in so many examples?

The superficial reasoning along generic and ahistoric concepts goes together with a use of the scholarly literature which relies too much on the handbooks and misses relevant recent work ${ }^{3}$, and with a presentation which suffers from mistakes in non-English names ${ }^{4}$ and from too many typos; it would be too much to expect indexes. In short: there still is much to be done on the topic, and the present volume is apt to mislead any serious non-specialist.

Fritz Graf

(Chicago/Basel)

Françoise Frontrsi-Ducroux, Jean-Pierre Vernant, Dans l'œil du miroir, Paris, Éditions Odile Jacob, 1997. 1 vol. $14,5 \times 22 \mathrm{~cm}, 298$ p., 30 fig. ISBN : 27381-0497-5.

« Ouvrage en trois parties et livre à deux voix. » Tel se définit d'emblée un parcours qui porte en ses extrémités la reconquête progressive par Ulysse de son identité et de son statut de roi, et en son centre une longue réflexion sur le miroir comme objet culturel en Grèce ancienne.

Les deux chapitres dus à J.-P. Vernant, s'il n'y est pas question d'un miroir de toute façon inexistant dans l'épopée, relisent l'Odyssée comme poème de la mémoire. Sont analysées tour à tour les métamorphoses du héros, mendiant loqueteux ou héros à l'éclat divin, la ruse autour de son nom dans la caverne de Polyphème, la mise à l'épreuve de la fidélité à sa propre mémoire chez les Lotophages, Circé ou Calypso. Mais c'est « au miroir de Pénélope » que se renouent définitivement les fils de l'identité du héros. C'est sa femme qui renvoie à Ulysse l'image de celui qu'il est redevenu.

1 Especially since the polemic focusses entirely on Burkert and overlooks the more recent and detailed work by Renate Schlesier, Olympian versus cbibonian religion, in Scirpta Classica Israelica, 11 (1991/92), p. 38-51, and Olympiscbe Religion und cbtboniscbe Religion, in U. Bianchi (ed.), The Notion of "Religion" in Comparative Researcb. Selected Proceedings of the XVIth Congress of the International Association for the History of Religions, Rome, 3rd-8th September 1990, Roma, 1994, p. 301-310.

2 See the list in $L I M C$, VI (1995), p. 998-1000; at least with some Hekataia, the central column served as support of something (nrs, 116. 127).

3 E.g. the article Hekate in LIMC VI, or the recent work on Enodia, P.A. PANTos,

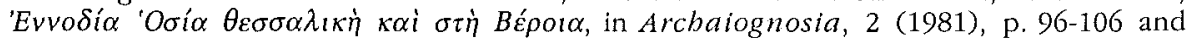


E. Wallinger, Hekates Töcbter. Hexen in der römiscben Antike, Wien, 1994, a book whose existence already undermines some initial claims of Rabinowitz; or most of the more recent work on ancient magic.

4 An anthology from chapter I:1: Uesener instead of Usener, Rhode instead of Rohde, Heckenback instead of Heckenbach. 